\title{
Nursing Image As a Profession and Self -Esteem Among Secondary School Students in Dakahlia Governorate
}

\author{
EmanMansoureFouda ${ }^{1}$, WafaaFathi Sleem ${ }^{2}$, Hind Abdulla mohamed ${ }^{3}$ \\ ${ }^{(1,3)}$ Nursing Administration, Faculty of Nursing,Port Said University, (2) Nursing Administration, Facultyof \\ Nursing, Mansoura University, Egypt.
}

\begin{abstract}
Background: Nursing profession is composite, energetic and assorted, so nurses still encounter confrontations concerning their image that has extensive trace on their decision to take up and remain in nursing and to contribute to better positive health care outcomes. Self-esteem has its effect on how student nurses think, feel, communicate, and motivate themselves and act which with-no-doubt impacts on the care patients receive.

Aim: The study aimed to detect the relationship between nursing image as a profession and self-esteem among secondary school students in Dakahlia Governorate.

Methods: A descriptive co-relational study was utilized with a sample of (420) nursing students that were selected from nursing secondary schools inDakahlia Governorate.

Tools of data collection:Two tools were used; Image of Nursing as a Profession Questionnaire and Self-Esteem Inventory.

Results: Revealed a positive perception towards nursing image as a profession. According to nursing students' perceptions the most apparent factors that had positive influence on nursing image are parents' opinion, relationship with medical staff in clinical training settings and teaching staff in the school of nursing. They also mentioned that the greatest factors that had negative influence on nursing image are public image of nursing and the media portrayal of nursing. Moreover, the majority of nursing students in the three grades had low selfesteem.

Conclusion:According to participants, there was no correlation between self-esteem and image of nursing as a profession.

Recommendation: It is recommended to enhance the professional behavior of nursing students through inservices training program to improve the image of nursing as a profession, and also introduce strategies to enhance nursing students' level of self-esteem.
\end{abstract}

Keywords: Image of nursing, self-esteem, profession,nursingstudents.

\section{Introduction}

The nursing profession has entered the $21^{\text {st }}$ century with the developing issue of demand for nursing personnel increasingly surpassing the supply of nurses (Cowin, 2002). The choice to enter nursing, to stay in nursing and to advance nursing, is probably the after-effect of nurses' view of the image of their job (Miller, Chapman\& Francis, 2006).

Through the past years, nursing image has changed to a great deal. The nursing image is controlled by how the public and the nurses themselves perceive this profession (Gordon\& Nelson, 2005). Image refers to the tangible or visible representations and/or perceptions resulting from a person's conduct as a professional, linked to competence and ethical behaviour(Nurses Association of Botswana, 2010). Put differently, the feeling and opinion we leave with others (Kunde,2010). Image is particularly apparent in our lives, because it impacts our collaboration with and expectation towards those around us, and passes on messages of how we see them (AmericanSociety of Registered Nurses. 2007).

Nurses involve the dominant part of healthcare personnel, and they are the foundation of the healthcare sector but generally they are unseen on account of the low public image of nursing (Waters, 2005). The public has a poor image of nursing. And this major topic has effects on the persons who choose nursing as a profession regarding the quality, quantity and attitudes. As long as the public are continuously presented with an erroneous and negative image of nursing, they will see the nursing profession undesirable(Luciana, B. L., Isabel, A. C., Gilberto, T. S. \&Moacyr, L. C. 2009).

Self-concept, self-esteem, recruitment, retention, and performance of the nursing students are all influenced by their perception towards the nursing profession image. Therefore, nurses with positive images towards their profession, will have progressive and more grounded relations with their patients, associates and community as a whole(Chauke, 2014). In addition, self-esteem can be enhanced by the positive feedback taken from the public (Taha, Mansour, Sobhy \& Youness, 2011).

The discernment the individual has of his or her self-worth refers to the term 'Self-esteem(Clara, 2007). Besides, self-esteem has an impact on how student nurses think, feel, encourage themselves and act 
Nursing Image as a Profession and Self-Esteem among Secondary School Students in Dakahlia...

which with no doubt influences the care and service their patients get. It was reported that nursing students with low self- esteem have an effect on the level and the quality of patient care in a negative direction and is associated with a host of social and academic problems. From another point of view, student nurses who have high self-esteem are proud of their work, feel confidence, and show respect and concern for both patients and associates(Unsar\&Issever, 2003).

Additionally, research has demonstrated that low self-esteem is often an indicator for the utilization of maladaptive strategies, such as self-handicapping and learned helplessness, at school. Adolescents who have low self-esteem are likely to take a lot of maladaptive strategies while on the contrary those with high selfesteem take more adaptive achievement strategies(Aunola, Stattin\&Nurmi,2000).

\subsection{Significance of the study}

Researchesreveal that to improvethe performance of nurse's job and decrease their turnover willingness, it is essential to work on and improve the self-image and public image of nurses (Takase, Maude \&Manias, 2006).If we identify the image of the nursing profession from the nurses' view, itwillhelp the business owners, curriculum specialistsand nursing politicians to upgradethe activities for preparingnursing and at the same time, the psychological needs of the students at the nursing schools should be appreciated(Chauke, 2014).In Egypt, we don't know enough about student nurses' perception of nursing and its relation to selfesteem.

\section{2. Research aim}

The aim of this study is to detect the relationship between nursing image as a profession and selfesteem among secondary school students in Dakahlia Governorate.

\subsection{Research questions}

1.What is the nursing students' perception toward the image of nursing as a profession?

2. What are thefactors influencing the nursing image as a profession?

3. What are the self-esteem levels among nursing students?

4. Is there a relationship between the nursing image as a profession and self -esteem?

\subsection{Design}

\section{Material And Methods}

A descriptivecorrelation research design was utilized in this study.

\subsection{Setting}

This study was carried out in the nursing secondary schools at Dakahlia Governorate: Five schools were selected out of 15 schools, which represent all the Dakahlia Governorate nursing secondary schools, by systematic random sample namely:(MehaltDmanh school, Sherbeen school, BanyEbidschool,Aga school,Elmataria school)

\subsection{Subject}

The Sample of the present study consisted of all nursing students from the three grades in the above mentioned schools (422) students. The participants were chosen with no age limit, with all available educational levels and willingness to participate in the study.

\section{4 .Tools of data collection}

Two tools were used to collect the necessary data for the study. Image of nursing as a profession questionnaire and a self-esteem inventory.

Tool I: Image of Nursing as a Profession Questionnaire:This tool was developed by Gamil (2006) and modified by the researcher to assess the nursing students' perception toward the image of the nursing as a profession and the factors affecting it. It consists of three parts. The Cronbach's alpha for internal consistency was 0.86 .

Part I: Personal characteristics of the study subjects:

It comprises: the residence area, parents' level of education, parents' job, and the academic year of the nursing students. 
Part II: Nursing students' perception about the image of nursing as a profession:

The aim of this part was to assess the nursing students' perception of the image of nursing as a profession. It consisted of 31-items that were categorized under four clusters, namely; nursing professiondescription (12items), social perspective (8items), benefits of the nursing profession (4 items) and the different roles of the nurse in the health care setting $(7$ items $)$. That were measured on a five point Likert scale: strongly agree $=(5)$; agree $=(4)$; uncertain $=(3)$; disagree $=(2)$; strongly disagree $=(1)$. A higher score indicates perception of a positive nursing image.

Part III: Factors influencing the nursing image as a profession among nursing students:

The aim of this part was to detect the factors influencing the nursing image as perceived by nursing students. It was classified into two domains. A higher score indicates higher perception about factors influencing the nursing image.

The firstdomain:It was used to detect the specific factors. It consists of 37 items divided into four factors, namely: work condition (21 items), relationship (6 items), nursing staff uniform (4items), and nursing courses (6 items). Students' responses were measured on a five point Likert scale; very positive $=(5)$, positive influence $=(4)$, no influence $=(3)$, negative influence $=(2)$, very negative influence $=(1)$.

The second domain: It was used to detect other miscellaneous factors. They were assessed by using five open ended questions.

Tool (II): Self-Esteem Inventory:This tool was developed by Coopersmith(1967), and modified byRydem(1978). It consists of (58) items to measure self-esteem of nursing students. The possible response (like me) or (not like me) for each item. The Cronbach's alpha for internal consistency was 0.81 .

Scoring system:Lie Scale items: 1, 6, 13, 20, 27, 34, 41, 48. If a participant answered "like me" for 3 or more of these items, it suggests that he or she is trying too hard to present him or herself in a positive light. These participants should not be included in the analyses.

High Self Esteem Items were:

"Like Me" on 2, 4, 5, 10, 11, 14, 18, 19, 21, 23, 24, 28, 29, 32, 36, 45, 47, 55, 57

"Unlike Me" on 3, 7, 8, 9, 12, 15, 16, 17, 22, 25, 26, 30, 31, 33, 35, 37, 38, 39, 40, 42, 43,44, 46, 49, 50, 51, 52, $53,54,56,58$.

\subsection{Methods}

- An official agreement was taken from each authorized person and the heads of the five schools to carry out the study. Also the aim and objectives of the study have been clarified to the headmasters to gain their support and cooperation.

- The self-esteem inventory was translated into Arabic and adapted to fit the Egyptian culture by the researcher and translated back into English.

- The study tools were submitted to a panel of five experts in the field of the study from the Nursing College to be tested for its validity. And the experts agreed on the tools items and they had no negative comments.

- $\quad$ Reliability of the self-esteem inventory was checked by testing for its internal consistency using Cronbach Alpha reliability test. Reliability of the scale was found 0.81 .

- A pilot study was carried out on $10 \%$ of the studied sample with total number 42 from different nursing schools at Dakahlia government, in order to test clarity and applicability of the tool, also to estimate the needed time to fulfill the questionnaires.

- Tools were reformed and presented in the final form. Those who took part in the pilot study were excluded from the main study sample.

- Ethical issues were raised by taking verbal consent for participation from every pupil after explaining the aim and nature of the study and the procedure of data collection.

- The researchers have emphasized that the participation is voluntary and the participants have the right to withdraw at any time.

- $\quad$ The students were interviewed with the researcher in groups in their classes in order to collect data. Each sheet took about 30 - 40 minutes to be answered.

- $\quad$ The data collection period extended for 4 months, from the beginning of June to the end of September 2014. Three days per week were specified for data collection (Sunday, Tuesday \& Thursday) from 8 to 11 AM.

- All data will remain confidential and be anonymous using a series of research codes. All recordings or transcripts will contain corresponding codes. Research codes are only known by the researchers. 
Nursing Image as a Profession and Self-Esteem among Secondary School Students in Dakahlia...

\subsection{Data analysis}

Data was coded, computerized and then analyzed using the Statistical Package for Social Science (SPSS) software package version 20.0. Minimum and maximum, mean and standard deviation was calculated for the quantitative data. While using frequency \& percentage for the qualitative data, $\chi^{2}$ Test and Pearson's correlation coefficient were used, statistical significance was considered at the 0.05 level.

\section{Results}

Table (1): Distribution of the nursing students according to their personal characteristics ( $n=422)$.

\begin{tabular}{|l|l|l|}
\hline \multirow{2}{*}{ Personal characteristics } & \multicolumn{2}{|l|}{$\begin{array}{l}\text { Total nursing students } \\
(\mathrm{N}=422)\end{array}$} \\
\cline { 2 - 3 } & No & $\%$ \\
\hline Residence & & \\
Rural & 283 & 67.1 \\
Urban & 139 & 32.9 \\
\hline Father's educational level & & \\
Illiterate & 50 & 11.8 \\
Read and write & 70 & 16.5 \\
Preparatory & 58 & 13.7 \\
Secondary & 186 & 44.0 \\
University & 58 & 13.7 \\
\hline Father's job & & \\
Governmental employee & 132 & 39.1 \\
Laborer & 128 & 30.3 \\
Trader & 42 & 9.9 \\
Farmer & 104 & 24.6 \\
Retired & 16 & 3.7 \\
\hline Mother's educational level & & \\
Illiterate & 85 & 20.1 \\
Read and write & 51 & 12.0 \\
Preparatory & 37 & 8.7 \\
Secondary & 209 & 49.5 \\
University & 40 & 9,4 \\
\hline Mother's job & & \\
Housewife & 333 & 78.9 \\
& 89 & \\
Occupied & & \\
\hline
\end{tabular}

Table (1) shows the distribution of the students according to their personal characteristics. As the table indicates that, 422 nursing student participated in the study. About two thirds of them live in the rural areas. The high percentage of students reported that, their fathers and mothers had secondary educational level. Regarding fathers' jobs, it was observed that, the minority of students' fathers were retired, while the rest of them were workers. In addition, the majority of students' mothers were housewives.

Table (2): Distribution of nursing students' perception toward the image of nursing as a profession concerning nursing profession description $(n=422)$.

\begin{tabular}{|c|c|c|c|c|c|c|c|c|}
\hline \multirow{3}{*}{$\begin{array}{l}\text { Nursing profession description } \\
\text { 1-A professional discipline with a unique } \\
\text { body of knowledge and skills. }\end{array}$} & \multicolumn{2}{|c|}{ Agreement } & \multicolumn{2}{|c|}{ Disagreement } & \multirow{2}{*}{\multicolumn{2}{|c|}{ Mean \pm SD }} & \multirow{3}{*}{$\begin{array}{l}X^{2} \\
22.80 \\
\end{array}$} & \multirow{3}{*}{$\begin{array}{l}\mathrm{p} \text {-value } \\
0.004^{*}\end{array}$} \\
\hline & \multirow{2}{*}{$\begin{array}{l}\text { No } \\
341 \\
\end{array}$} & \multirow{2}{*}{$\%$} & \multirow{2}{*}{$\begin{array}{l}\text { No } \\
81 \\
\end{array}$} & \multirow{2}{*}{$\begin{array}{l}\% \\
19.1 \\
\end{array}$} & & & & \\
\hline & & & & & 1.89 & \pm 1.03 & & \\
\hline 2-An Interesting profession. & 323 & 76.5 & 99 & 23.4 & 1.98 & \pm 1.06 & 23.65 & $0.003^{*}$ \\
\hline 3-Helping others to live healthy lives & 418 & 99.0 & 4 & 1.0 & 3.58 & \pm 0.50 & 5.52 & 0.70 \\
\hline 4-Requiring ethics in practice. & 364 & 86.2 & 58 & 13.7 & 2.70 & \pm 0.98 & 18.50 & $0.02 *$ \\
\hline $\begin{array}{l}\text { 5-Requiring scientific knowledge, creative } \\
\text { and intellectual skills. }\end{array}$ & 363 & 86.0 & 59 & 13.9 & 2.60 & \pm 1.21 & 9.34 & 0.31 \\
\hline $\begin{array}{l}\text { 6-Helping others to cope with their health } \\
\text { problems. }\end{array}$ & 415 & 98.3 & 7 & 1.6 & 2.35 & \pm 0.53 & 2.28 & 0.89 \\
\hline 7-Caring for others during illness. & 419 & 99.2 & 3 & 0.8 & 3.89 & \pm 0.52 & 12.95 & $0.04 *$ \\
\hline 8-Taking care of Patient's physical needs. & 416 & 98.5 & 6 & 1.4 & 3.00 & \pm 0.96 & 5.11 & 0.53 \\
\hline $\begin{array}{l}\text { 9-Taking care of Patient's psychological } \\
\text { needs. }\end{array}$ & 391 & 92.6 & 31 & 7.3 & 3.44 & \pm 0.54 & 6.32 & 0.61 \\
\hline 10-Taking care of Patient's social needs. & 357 & 84.5 & 65 & 15.4 & 2.23 & \pm 0.66 & 3.12 & 0.93 \\
\hline $\begin{array}{l}\text { 11-Taking care of Patient's spiritual } \\
\text { needs. }\end{array}$ & 311 & 73.6 & 111 & 26.3 & 1.50 & \pm 0.84 & 6.92 & 0.55 \\
\hline 12-Working with high technology. & 282 & 66.8 & 140 & 33.1 & 1.86 & \pm 1.02 & 163.9 & $0.000^{*}$ \\
\hline
\end{tabular}

Table (2) displays the nursing students' perception toward the image of nursing as a profession concerning nursing profession description. As table indicated that nursing students had positive perceptions 
Nursing Image as a Profession and Self-Esteem among Secondary School Students in Dakahlia...

regarding most items of nursing profession description. The highest percentage of nursing students' reported that the nursing profession is caring for others during illness, helping others to lead healthy lives, taking care of patients' physical needs, helping others to cope with their health problems, taking care of patients' psychological needs, requiring ethics in practice and scientific knowledge. There is an apparent statistically significant difference among students' responses within the items 1, 2, 4,7 and12.

Table (3): Distribution of nursing students' perception toward the image of nursing as a profession concerning social perspective $(n=422)$.

\begin{tabular}{|c|c|c|c|c|c|c|c|c|}
\hline \multirow[t]{2}{*}{ Social perspective } & \multicolumn{2}{|c|}{ Agreement } & \multicolumn{2}{|c|}{ Disagreement } & \multirow{2}{*}{\multicolumn{2}{|c|}{ Mean \pm SD }} & \multirow[t]{2}{*}{$\mathrm{X}^{2}$} & \multirow[t]{2}{*}{ p-value } \\
\hline & No & $\%$ & No & $\%$ & & & & \\
\hline 1-Similar to a servant's job. & 163 & 38.6 & 259 & 61.3 & 1.30 & \pm 1.44 & 6.25 & 0.62 \\
\hline 2-An Important profession in Egyptian society. & 345 & 81.7 & 77 & 18.2 & 3.26 & \pm 1.58 & 7.13 & 0.52 \\
\hline 3-Subordinate to the medical profession. & 360 & 85.3 & 62 & 14.6 & 2.75 & \pm 1.10 & 10.51 & 0.23 \\
\hline 4-A prestigious profession. & 357 & 84.5 & 65 & 15.4 & 2.60 & \pm 0.91 & 7.18 & 0.52 \\
\hline 5-Non respectable profession. & 149 & 35.3 & 273 & 64.6 & 1.87 & \pm 0.95 & 13.13 & 0.11 \\
\hline 6-A women's work. & 377 & 89.3 & 45 & 10.6 & 3.50 & \pm 1.69 & 19.09 & $0.01 *$ \\
\hline 7-A men's work. & 309 & 73.2 & 113 & 26.7 & 2.21 & \pm 0.98 & 16.53 & $0.04 *$ \\
\hline 8--Being appreciated by others. & 302 & 71.5 & 120 & 28.4 & 1.98 & \pm 1.08 & 16.41 & $0.04 *$ \\
\hline
\end{tabular}

Table (3) reveals the nursing students' perception toward the image of nursing as a profession concerning social perspective. It is noticed that, the majority of the nursing students reported that the social perspective of nursing as a profession is a women's work, subordinate to the medical profession, a prestigious and important profession in the Egyptian society $(89.3 \%, 85.3 \%, 84.5 \%$, and $81.7 \%$ ) respectively. Meanwhile, the minority of them reported that nursing is similar to a servant's job and a non-respectable profession (38.6\%, $35.3 \%$ ) respectively. There is an apparent statistically significant difference among students' responses within the items6, 7, and 8 .

Table (4): Distribution of nursing students' perception toward the image of nursing as a profession concerning benefits of nursing profession $(n=422)$

\begin{tabular}{|c|c|c|c|c|c|c|c|c|}
\hline \multirow[t]{2}{*}{ Benefits of nursing profession } & \multicolumn{2}{|c|}{ Agreement } & \multicolumn{2}{|c|}{ Disagreement } & \multirow{2}{*}{\multicolumn{2}{|c|}{ Mean \pm SD }} & \multirow[t]{2}{*}{$\mathrm{X}^{2}$} & \multirow[t]{2}{*}{ p-value } \\
\hline & No & $\%$ & No & $\%$ & & & & \\
\hline 1-An Autonomous profession. & 190 & 45.1 & 232 & 54.9 & 1.63 & \pm 0.83 & 8.69 & 0.37 \\
\hline 2- Opportunity for Promotion. & 323 & 76.5 & 99 & 23.4 & 2.94 & \pm 0.99 & 17.14 & $0.03 *$ \\
\hline 3-Opportunity for Being a leader. & 308 & 72.9 & 114 & 27.0 & 2.03 & \pm 0.99 & 14.93 & 0.06 \\
\hline 4-Opportunity for educational progress. & 367 & 86.9 & 55 & 13.0 & 3.10 & \pm 1.26 & 9.21 & 0.33 \\
\hline
\end{tabular}

Table (4) illustrates distribution of the nursing students' perception toward the image of nursing as a profession concerning the benefits of the nursing profession. In this table the majority of nursing students $(86.9 \%)$ state that the nursing benefit is the opportunity for educational progress. Whereas, $(45.1 \%)$ of them report that nursing is an autonomous profession. There is a statistically significant difference among students' responses within the second item (opportunity for promotion).

Table (5): Distribution of nursing students' perception toward the image of nursing as a profession concerning different roles in the health care setting $(n=422)$.

\begin{tabular}{|c|c|c|c|c|c|c|c|c|}
\hline \multirow{3}{*}{$\begin{array}{l}\text { Nursing students' perception toward } \\
\text { different roles in the health care setting } \\
\text { Care provider role }\end{array}$} & \multicolumn{2}{|c|}{ Agreement } & \multicolumn{2}{|c|}{ Disagreement } & \multirow{2}{*}{\multicolumn{2}{|c|}{ Mean \pm SD }} & \multirow[t]{2}{*}{$\mathrm{X}^{2}$} & \multirow[t]{2}{*}{ p-value } \\
\hline & No & $\%$ & No & $\%$ & & & & \\
\hline & 420 & 99.5 & 2 & 0.5 & 8.61 & 3.83 & 9.26 & 0.16 \\
\hline Documentation role & 417 & 98.8 & 5 & 1.2 & 6.96 & 2.3 & 10.2 & 0.12 \\
\hline Educator role & 402 & 95.3 & 20 & 4.7 & 4.57 & 1.74 & 13.0 & 0.11 \\
\hline Researcher role & 390 & 92.4 & 32 & 7.6 & 5.22 & 2.27 & 19.6 & $0.01 *$ \\
\hline Advocacy role & 384 & 90.9 & 38 & 9.1 & 3.27 & 1.29 & 20.9 & $0.007 *$ \\
\hline Manager role & 382 & 90.5 & 40 & 9.5 & 7.02 & 3.33 & 17.6 & $0.02 *$ \\
\hline
\end{tabular}

Table (5) represents the nursing students' perception toward the image of nursing as a profession concerning the different roles in the health care setting. It is noticed that most students $(99.5 \%, 98.8 \%)$ perceive that their role is a care provider, followed by documentation role. Whereas, $(90.5 \%)$ of them report a managerial role. 
Figure (1): Mean score of nursing students' perception toward influence of working condition factors on image of nursing as a profession.

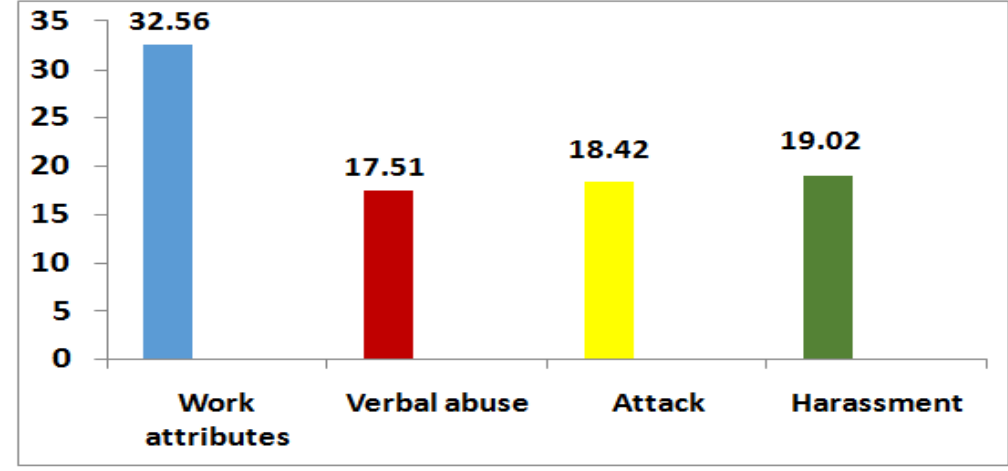

Figure (1)demonstrates the mean score of the nursing students' perception toward the influence of the working condition factors on the image of nursing as a profession. It is obvious that workattributes is the dominant factor affectingthestudent nurses' perception, while the verbal abuse was the least affecting factor on the nursing image.

Figure (2):Frequency distribution of nursing students according to their perception about factors that influence the image of nursing as a profession.

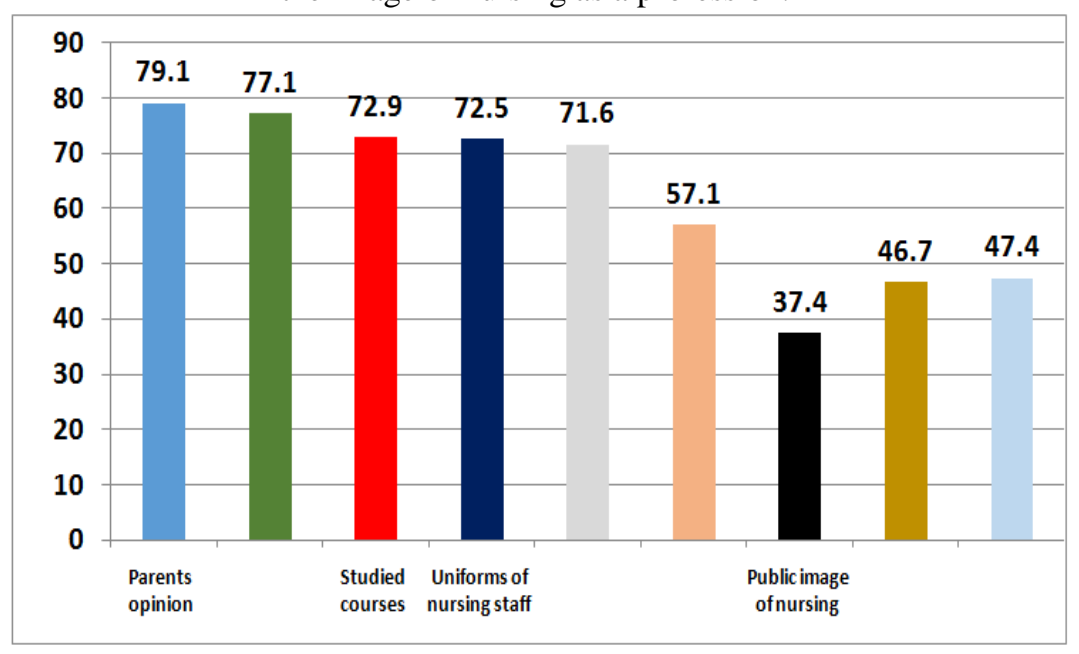

Figure (2) shows the frequency distribution of the nursing students according to their perception of the factors that influence the image of nursing as a profession. It is obvious that the majority of the nursing students perceive that the factors that have positive influence on the nursing image are the parents' opinions, the relationship with the medical staff in the clinical training settings, the studied courses, uniforms of the nursing staff, the teaching staff at the school of nursing, and the working condition factors $(79.1 \%, 77,1 \%, 73.1 \%, 72.5$ $\%, 71.6 \%, 57.1)$ respectively. Meanwhile, the public image of nursing, and the media portrayal of nursing have negative influence on nursing image.

Figure (3): Self-esteem levels as reports by the studied sample.

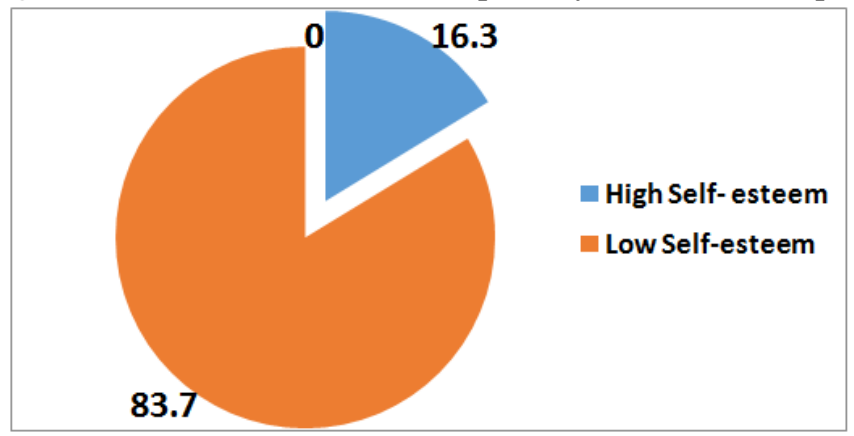


Nursing Image as a Profession and Self-Esteem among Secondary School Students in Dakahlia...

Figure (3) portraysself-esteem levels as reported by the nursing students. It is noticed that the majority $(83.7 \%)$ of the students have low self-esteem, while the minority $(16.3 \%)$ of them havehigh self-esteem.

Table (6): Correlation between image of nursing as a profession and level of self-esteem among nursing students $(n=422)$.

\begin{tabular}{|l|l|l|}
\hline Image of nursing as a profession & \multicolumn{2}{|c|}{ Self-esteem } \\
\cline { 2 - 3 } & $\mathbf{R}$ & $\mathbf{p}$ \\
\hline Nursing image & .095 & 0.051 \\
\hline
\end{tabular}

Table (6) reveals a correlation between image of nursingas a profession and the level of self-esteem among the nursing students. It is evident that there is no statistically significant correlation between the image of nursing as a profession and self-esteem among the nursing students.

\section{Discussion}

One of the major issues in the field of attracting more seekers to the nursing profession is changing the image of the nursing profession. A negative image has negative consequences, in the quality and quantity of persons who choose nursing while a positive image leads to several positive professional outcomes (Ibrahim, Akel\& Mohammed,2015).

In the scopedealing with the image of nursing and self-esteem, it is very important to focus on the students in secondary education. This study aims to find if there is a relation between image of nursing as a profession and self-esteem among nursing students.

Concerning the nursing students' perception of nursing as a profession, the study results indicated a positive perception regarding most items of the four dimensions of the nursing image as profession;nursing profession description, social perspective, benefits of nursing profession and different roles of nurse in the health care setting.This might be attributed to the fact that nursing as a career became more valued and treasured.This is the same viewpoint ofAbdlkarim ., El Khouly., \&Reizian, (2004) who found out that the nursing profession was seen prized, valued and secure so it became striking. The result of this study is in accordancewithAbdel El-Halem ., El Hawashy., Gamal El-Dein ., Taha, (2011)whoconcluded that the greater part of nursing students held a positive perception of the nursing image as a profession.

From another perspective, nursing is being badly affected by a non-optimisticcommon image in the Arab world. The publicviewusuallyseesthe profession of nursingas a women's job with very low economic welloff, respect, prestige and she is always subordinate.In the same stream,Tan-Kuick (2012)concludedthatsecondarystage students' inclination to study nursing in the college stage is significantly impacted by the negative common social image of nursing.

Gaber \& Mostafa (2013) emphasized that nurses undertake a focal part in conveying medicinal services; they are experts steered by their knowledge and technical skills, and ready to help people of any age and any social background.Findings of the present study revealed that the highest percentage of nursing students had positive perception regarding description of nursing profession,thatis caring for others during illness, helping others to lead healthy lives, taking care of patients' physical and psychological needs, helping others to cope with their health problems, requiring ethics in practice and a professional discipline with a unique body of knowledge and skills.

This conclusion goes with Ibrahim et al., (2015) who found that the students of nursing in Egypt adopt a positive belief in the feature of nursing profession description as a philanthropic and based on ethical standards professionbesides the health care.Also, in the same context National Cancer Institute (2014) denoted that students were concurred that the nurse's duty is to help other people to live healthily, help them to adapt to their health troubles, and provide care for them when being sick. These results were compatible with Currid (2012) who stated that the nurse ought to care for the patients' needs in all forms - psychological, spiritual, social, and physical.

Regardingthenursing students' perception toward thesocialperspective, the study results revealed that the social perspectiveof nursing as a profession was in the second rank of the nursing image aspects according to opinions of the nursing students. This may be due to the traditions and culture of our societies that were reflected in the perceptions of nursing as a profession.In this respect,Tawash ., Seamus ., \& Edger, (2012) delineated that the positive impression of nursing as giving care and aid for other people may serve as a main thrust in building up a system to strengthen the social view about nursing in the community. Besides Valizadeh\& Ali(2008) upheld this result and recognized that to reach the goalof drawing in more people to the nursing job, a desirableimage of nursing should be enrooted by the educational system and the society.

In this respect,study results illustrated that the majority of the nursing students perceived that nursing is a women's work. This finding might be due to the culture of our societies considering that the nursing profession is a more women's work than a men's work.In addition, our communities need more campaigns and targeted recruitments to draw men into the profession.Thisinterpretation was bolstered byKalisch., Begeny, 
Nursing Image as a Profession and Self-Esteem among Secondary School Students in Dakahlia...

\&Neumann ., (2006) and Keogh \&O'Lynn (2007) who elucidated that the society in the Arab area adopts negative picture about the nursing profession, and this leads the nursing role is fundamentally questionable, especially to men. Additionally, media gives a negative picture that concentrates for the most part on an unconstructive picture of a male medical attendant. This resultgoes in accordance with Mee (2006) who found that none of the young men needed to wind up a nurse and just $36.0 \%$ of the young men considered the nurse as both female and male job. Moreover, Kemmer\& Silva (2007) demonstrated that most people see the nurse as female and caring, however not inevitably as autonomousexperts of health care. In this regard, National Association of Student Nurses (2012) stated the existence of an ongoing negative image of nursing among the male nursing students.

Also, the current study findings illustrated that the majority of the nursing students perceived that the nursing profession was subordinate to the medical profession. The researchresultagrees with Savi $\square$ \&agon (2008), they concluded that nursesbelieved that they were inferior to doctors. This finding was reliable with Cohen (2007) who expressed that Florence Nightingale portrayed the nurse as substandard compared to the doctor.

The findings revealed that nursing is a prestigious and important profession in Egyptian society.Thisresult is consistent with Chauke (2014) who reported that the students at nursing schools confirmed a change in their perception of nursing as a regarded and acknowledged job - and this was very positive change. These results were compatible with Riffkin (2014) who expressed that, nursing is a regarded as a job that people respect and admire. Also, Jenkins \& Stewart (2010) delineated that nursing is a unique profession and hospitals are not industrial buildings managing soulless objects or information.Contradictoryto these perspectives, Brodi, et al., (2004)presumedthatnursing as a job of respect was seen by a small number of students at the nursing schools, but as "male's work" seen by a big number of them and other members in the society. On opposite withVaraei ., Vaismoradi ., Jasper., Faghihzadeh, (2012)who reported that the prestige and the socialrole features, societal position and salary, and mental self-portrait negatively affected the nursing image.

Study resultsrevealed that the benefit of nursing profession was in the third rank of the nursing image.It is evident that the nursing students had a positive perception regarding most items of the nursing professionbenefits. Obviously, nursingprofessionattractstudentsto enter this career due to the fact that they have opportunity for educational progress, forpromotion and for being a leader.

In this respect, Ibrahim etal, (2015)found that theEgyptian and Jordanian students at the nursing schoolsperceive the nursing job positively regarding its benefits. Moreover, the nursing job is an alluring occupation since it offers genuine work options and a steady business with appropriate pay rates. In addition, Beck (2000)\&Chauke (2014) reported that as soon as students graduate from the nursing schools and colleges, they are hired and start working both in western and Arab countries.

With regardtothe role of nurse in the health care setting as perceived by the nursing students, the findings of the present study revealed that approximatelyall students perceived that their role would be a care provider.Whereas, the majority of the students agreed that a nurse's role would not only be based on providing care for the patients but alsoa nurse must have a documentation, educator, counseling, researcher, advocacy, and managingroles. Theseresults were upheld by Herron-Rice et al., (2009) who expressed that, the nurse'sduty incorporates giving consideration, documentation, instruction, advising, supporter, research and administration.

Itis obvious that the highest percentage of the nursing students perceive that the factors that have positive influence on the nursing image are parents' opinion, relationship with medical staff in clinical training settings and the teaching staff at the nursing school. Harmonious with the researchers' perspective,Al Jarrah (2013) who inferred that the nursing profession's image is greatly affected by family members' opinion and the relation with the medical staff.Besides,Tan-Kuick (2012)noticedthat the students' decision to complete their college level studying nursing is significantly influenced by the image their peers and parents have about the nursing profession.

In this regard,Abdel El-Halem et al. (2011) highlighted that the clinical training had a positive influence on the students at the nursing schools. This might be because they develop while interacting with their clinical mentors. It might be explained that the existence with the peer professionals in real contexts and setting gives opportunities to apply what they learn into practice and elucidate the dynamic part of student nurses. Moreover, Emeghebo (2012) reported that nurses' view of their job is impacted by collaborations with others in the field of health caring.Likewise,Abualrub ., Omari \& Abu Alrub, (2009) denoted that in Jordan's hospitals the level of job satisfaction was clearly upgraded by the level of social backingthe nurses receive from their associates. Everyone in the nursing staff ought to be urged to cooperate as a group and share objectives, in as much as collaboration, cohesiveness, and shared visionhas been distinguished as mainstays for good work by the nursing staff(Miller, 2006). Unlike to this perspective, Gamel(2006)did a research in Egypt and found that the college academic staff had a negative influence on a great deal of the students and this was a result of the negative rapport between the instructors and the students. 
Nursing Image as a Profession and Self-Esteem among Secondary School Students in Dakahlia...

On the other hand,the current study findings indicated that the public image of nursing and the media portrayal of nursing are the greatest factors that have negative influence on the nursing image. Thisis due that the public image is predominantly based on misconceptions and stereotypes, which find their origins in distorted images of nurses in the media. This elucidation is upheld byGordon ., \& Nelson, $\mathbf{S}(\mathbf{2 0 0 5})$ who claimed that the media has influence in sustaining the image of the nurse as angels of mercy, the physician's assistant, companion and sexy associate. Because of such portrayals, most people see the nursing as a female job that is caring, however not inexorably as self-directed providers of the medicinal services (Takase., Maude., \& Manias, 2006\& Silva 2007).

In addition, nursing is viewed as having few possibilities for getting employed (Ben Natan\& Becker, 2010). Like these results of the current study, Twomey\&Meadus, (2008) reported that the cliché of nursing in public culture and the media influenced how the students perceive nursing. Furthermore, Ibrahim et al (2015) concurs that the way people view nursing is a powerful determinant restraining the nursing profession's image. This is contradicting withDonelan., Buerhaus., Des Roches., Dittus., \&Dutwin,. (2008) who illustrate that the American respect nursing as an occupation to a great extent.Kalisch et al. (2007) demonstrated that nurses are viewed as talented, qualified and respectable experts(Hoeve, Jansen \&Roodbol, 2013).

In this study, the majority $(83.7 \%)$ of students had low self-esteem. This result was expected because the study indicated that the majority of the students were from the rural areas and there was a significant relation between residence and self-esteem $(\mathrm{P} \leq 0.04)$; the students who reside in the rural areas had lower self-esteem than the students who reside in the urban areas. Thisresult was upheld by Peyrovietal., (2012)\&Ghezelbash ., Rahmani ., Peyrovi ., Inanloo, \&Shekarchian, (2015) who reported a significantly statistical relation between self-esteem and where the nurses were resided. Moreover, this result may be clarified by the study results that revealed that more than $33 \%$ of the nursing students concur that this job is like that of a housemaid which lacks respect because of the wrong media portrayals of nursing in ways that disregard the official necessities of the job and seen it with constrained employment chances. This is in accordance with Light stoneWalton, (1974) who claimed that self-esteem, can be modified and is not made to be unchangeable but rather affected by physiological, physical and environmental encounters; it is not innate but rather acquired. The family members and acquaintances are the source of this acquisition and they sustain culturally what is acquired and encountered.

The finding of the study was harmonious withEdwards., Burnard., Bennett., \&Hebden, (2010) who reported that the self-esteem values were low among study subjects.Moreover,Azizi., Khamseh ., Rahimi ., \&Barati, (2013) claimed that most of the nursing students had self-esteem with low levels. This is different with Farid\& Akhtar (2013) and Nikitha ., Jose., \&Valsaraj, (2014) their results mentioned that the students at nursing schools had self-esteem with high levels. Whereas, Burnard ., Hebden ., \& Edwards, (2001) concluded that undergraduate student nurses' had normal range of self-esteem. AdditionallySulimana\&Halabib (2007) found that nursing students had average self-esteem.

Regarding the relation between the image of nursing and self-esteem among the nursing students, the findings indicated that there was no correlation between image of nursing and self-esteem. These results go conversely with Jahromi ., Jahanbin ., Sharif ., Ghodsbin ., \&Keshavarzi, (2014) who presumed that the image the society has about nursing has a great effect on the nursing students' perception of nursing and is a direct reason for their low sel-esteem. Moreover, Hoeveetal.,(2014) reported that, the nurses' professional character and self-concept are derived from the image the public have in their community. Additionally, these results are diverged from Varaeietal.,(2012) who observed that nurses' mental self-view negatively affected the nursing image. Besides, nurses' performance, self-esteem, retention, employment and self-concept are clearly influenced by the perception of the student nurses toward the nursing profession's image. Hence, (Clara, 2007\&Chauke, 2014) reported that nurses with the positive image about their profession will have increasingly and more grounded relations with colleagues, the society and their patients in particular. In the meantime, Varaei et al.,(2012) observed that the nursing image was negatively influenced by the self-image the nurses have.

\section{Conclusion}

Based on thefindings of the present study, it can be concluded that the nursing students have positive perception toward most items of the nursing image as a profession.According to the nursing students' perceptions, the most apparent factors that have positive influence on the nursing image are parents' opinion, relationship with the medical staff in clinical training settings and the teaching staff at the nursing school.In addition, they also mentioned the greatest inhibiting factors that have negative influence, namely the public image of nursing and the media portrayal of nursing.Moreover, the majority of the nursing students in the three grades had low self-esteem.Finally, there was no correlation between self-esteem and the image of nursing as a profession. 
Nursing Image as a Profession and Self-Esteem among Secondary School Students in Dakahlia...

\section{Recommendations}

In accordance with the foregoing research, the points that follow are recommended and suggested:

1. In-service training and educational opportunities about image of nursing and self-esteem should be conducted.

2. Orientation programs about nursing as a profession should be applied for the nursing students starting out the career.

3. Utilizing the activities and strategies that develop students'perception of the nursing image and self-esteem.

4. Nursing students should be providedwith easy access to theeducational materials that develop the adequate skills and abilities to be competent at work.

5. More researches are needed to identify other contributing factors in nursing enhancement.

6. Some Research is needed on the integration of the image of the nursing profession in the nursing curricula.

\section{References}

[1]. Abdel El-Halem, G.E., El Hawashy, Z.I., Gamal El-Dein, A. A., Taha, E.E., (2011): Undergraduate Male Nursing students' Perception about the Image of the Nursing Profession. Journal of American Science; 7(3):614-23.

[2]. Abdlkarim, N., El Khouly, A., \&Reizian, A. (2004): Male student nurses: concerns, expectations and fears towards the profession. The 18th International Scientific Nursing Conference; 27.

[3]. Abualrub, R. F., Omari, F. H., \& Abu Alrub, A. F. (2009): The moderating effect of social support on the stress-satisfaction relationship among Jordanian hospital nurses. Journal of Nursing Management, 17, 870-878.

[4]. Al Jarrah, I. (2013): Associate nursing students' perceptions toward nursing profession in Jordan. European Scientific Journal February; 9(6): 1857- 7431.

[5]. American Academy of Nursing (AAN),(2007): Raise the voice. Retrieved from http://www. aannet.org.

[6]. American Society of Registered Nurses (ASRN.ORG), (2007): The Real Public Perception of Nurses. Journal of Nursing. vol.1:1-4.

[7]. Aunola, K; Stattin, H; Nurmi, J. (2000): Adolescent's achievement strategies, school adjustment, and externalizing and internalizing problem behaviors. Journal of Youth and Adolescence, 29 (3), 289-306.

[8]. Azizi, M., Khamseh, F., Rahimi, A., \&Barati, M. (2013): The relationship between self-esteem and depression in nursing students of a selected medical university in Tehran. IJPN; 1(1): 28-34.

[9]. Beck, C. (2000): The experience of choosing nursing as a career. Journal of Nursing Education; 39:320-322.

[10]. Ben Natan, M., Becker \& F. (2010): Israelis' perceived motivation for choosing a nursing career. Nurse Education Today 30 (4), 308-313.

[11]. Brodie, D., Andrews, G., Andrews, J., Thomas, G., \& Wong, J. \&Rixon, L. (2004): Perceptions of nursing: confirmation, change and the student experience. International Journal of Nursing Studies, 42, 721-733.

[12]. Burnard, P., Hebden, U., \& Edwards, D. (2001): Self-esteem and student nurses: an account of a descriptive study. Nurse Health Sci; 3(1):9-13.

[13]. Chauke, M. E., (2014): Transforming student nurses' image of nursing: an appreciative inquiry approach. A Dissertation Presented in Partial Fulfillment of the Requirements for the Degree Doctor of literature and philosophy, University of South Africa; 1-38.

[14]. Chaves, E., Simão, T., Oliveira, I., Souza, I., Iunes, D., \&Nogueira, D. (2013): Assessment of nursing students' self-esteem at a university in the South of Minas Gerais (Brazil). Invest educenferm; 31(2).

[15]. Clara, B. W. (2007): Nursing students' perceptions of the public image of nursing. A Dissertation Presented in Partial Fulfillment of the Requirements for the Degree Doctor of Philosophy, Capella University.

[16]. Cohen, S. (2007): The image of nursing. American Nurse Today, 2(5), 24-26.

[17]. Coopersmith, S. (1967): The antecedents of self-esteem. San Francisco: W. H. Freeman \& Co.

[18]. Cowin, L. S. (2002): The effects of nurses' job satisfaction on retention, an Australian perspective, Journal of Nursing Administration, 32(5),283-291

[19]. Currid, T. (2012): Meeting the psychological needs of the physically ill. Nursing Times; 108(46): 22-25

[20]. Donelan, K., Buerhaus, P., Des Roches, C., Dittus, R., \&Dutwin,D. (2008): Public Perceptions of Nursing Careers: The Influence of the Media and Nursing Shortages. Journal of Nursing. Economic. 26(3): 143-65.

[21]. Edwards, D., Burnard, P., Bennett, K., \&Hebden, U. (2010): A longitudinal study of stress and self-esteem in student nurses. Nurse Education Today; 30(1): 78-84.

[22]. Emeghebo, L. (2012): The image of nursing as perceived by nurses. Nurse Educ Today; 32(6):e49-53. doi: 10.1016/j.nedt .2011.10.015.

[23]. Farid, M., \& Akhtar, M. (2013): Self-esteem of secondary school students in Pakistan. Middle-East Journal of Scientific Research; 14(10): 1325-1330. DOI: 10.5829/idosi.mejsr.2013.14.10.2502.

[24]. Gaber, M. T. \& Mostafa, M. S. (2013): Comparison of nursing students 'perceptions about male nursing among Zagazing University in Egypt and Shaqra University in Saudi Arabia. Life Science Journal 10(4).

[25]. Gamel, R. E. (2006): The image of nursing as a profession among undergraduate nursing students and intern. M.D thesis, Alexandria university .Administration dep.

[26]. Ghezelbash, S., Rahmani, F., Peyrovi, H., Inanloo, M. \&Shekarchian, S. (2015): Comparison of self-esteem among first to fourth year nursing students from Universities of Medical Sciences in Tehran. Thrita; 4(1): e24336.

[27]. Gordon, S., \& Nelson, S. (2005): An end to angels. American Journal of Nursing, 105(5), 62-69.

[28]. Herron-Rice, L., Casey, R.L., Day, M., Friis, C.M., Girard, D., Harker, J.D., Juan, M.R., Panther, M.K., Sarisley, C., \&Schaeublin, T. (2009): Standards of clinical nursing practice and role delineations. Society of Gastroenterology Nurses and Associates, Inc. available at: http://www.sgna.org/Portals/0/Education/Practice\%20Guidelines/Standards ClinicalNursing Practice.pdf.

[29]. Hoeve, Y., Jansen, G., \&Roodbol, P. (2014): The nursing profession: public image, self-concept and professional identity. A discussion paper. Journal of Advanced Nursing; 70(2): 295-309.

[30]. Ibrahim, A. F., Akel, D. T., \&Alzghoul, H .W. (2015): Nursing Education Department Faculty of Nursing, Alexandria University. Egypt. Nursing Administration Department, Faculty of Nursing, Ain Shams University. Egypt Nursing lecturer, Al Balqa Applied University, Jordan journal of Education and Practice www.iiste.org ISSN 2222-1735 (Paper) ISSN 2222-288X (Online) Vol.6, No.14, 2015 
Nursing Image as a Profession and Self-Esteem among Secondary School Students in Dakahlia...

[31]. Izgiç, F., Akyüz, G., Dogan, O., \&Kugu, N. (2004): Social phobia among university students and its relation to self-esteem and body image. Can J Psychiatry; 49: 630-634.

[32]. Jahromi, Z., Jahanbin, I., Sharif, F., Ghodsbin, F., \&Keshavarzi, S. (2014): Investigation of the professional self-concept of nursing students in Shiraz, Iran. Cent Eur J NursMidw; 5(3): 112-116. doi: 10.15452/CEJNM.2014.05.0005.

[33]. Jenkins, M., \& Stewart, A.C. (2012): The importance of a servant leader orientation. Health Care Manage Rev; 35(1):46-54. doi: 10.1097/HMR.0b013e3181c22bb8.

[34]. Kalisch, J., Begeny, S. \& Neumann, S., (2006): The image of the nurse on the internet. Nursing Outlook; 55(4): 182-8.

[35]. Kemmer, L.F., \& Silva, M.J.P. (2007): Nurses' visibility according to the perceptions of the communication professionals. Rev latinoamEnfermagem; 15(2): 191-198.

[36]. Keogh B., O'Lynn C, (2007): Male nurses' experiences of gender barriers: Irish and American perspectives. Nurse Educator; 32 (6): 256-9.

[37]. Kunde, A. M., (2010): Being a Nurse: Perception of Baccalaureate Nurses One Year Post Graduation from an Accepted Program. University of Wisconsin Oshkosh. Published Master Thesis. 32.

[38]. Luciana, B. L., Isabel, A. C., Gilberto, T. S. \&Moacyr, L. C. (2009): An instrument to analyze secondary-level students' images about nurses. Rev Esc Enferm; 43(2):272-8 www.ee.usp.br/reeusp.

[39]. Mee, C.L. (2006): How you can shape nursing's image. Painting a portrait. Available at: http://www.nsna.org/Portals/0/Skins /NSNA/pdf/Imprint_NovDec06_Feat_C Mee.pdf.

[40]. Miler, J. F. (2006): Opportunities and obstacles for good work in nursing. Nursing Ethics, 13, 471-487.

[41]. Miller-R, K., Chapman, Y., Francis, K. (2006): "Historical, Cultural, and Contemporary Influences on the Status of Women in Nursing in Saudi Arabia". OJIN: The Online Journal of Issues in Nursing. Vol. 11, No. 3.

[42]. National Cancer Institute (2014): End-of-Life Care for People Who Have Cancer. Available at:http://www.cancer.gov/aboutcancer/advanced-cancer/care-choices/care-fact-sheet.

[43]. National Student Nurses' Association (NASA), (2012): Guidelines for planning image of nursing. Brooklyn: National Student Nurses' Association.

[44]. Nikitha, S., Jose, T., \&Valsaraj, B. (2014): A correlational study on academic stress and self-esteem among higher secondary students in selected schools of udupi district. Nitte University Journal of Health Science; 4(1): 106-108.

[45]. Nurses Association of Botswana, (NAB), (2010): Image campaign: Professional Image of a Nurse. Number. (2) 1-16.

[46]. Peyrovi, H., Ghezelbash, S., Ghorbani, A., Inanloo, M., Alizadeh, H., Haghani, H.,Aly, A., \&Mohamady, P. (2012): Relationship between self-esteem and demographic variables among undergraduate student nurses; 14 (4):0-0.

[47]. Riffkin, R. (2014): Americans rate nurses highest on honesty, ethical standards. Gallup. Available at: http://www.gallup.com/poll/ 180260/americans-rate-nurses-highest-honesty-ethical-standards.aspx.

[48]. Ryden, M. B. (1978): An adult version of Coopresmith Self-Esteem Inventory: Test re-tests reliability and social desirability. Psychological Reports 43:1189-1190.

[49]. Savi $\square$, B.S., \&Pagon, M. (2008): Relationship between nurses and physicians in terms of organizational culture: who is responsible for subordination of nurses? Croat Med J; 49(3): 334-343. doi: 10.3325/cmj.2008.3.334

[50]. Spouse, J., (2000): An impossible dream? Images of nursing held by pre-registration students and their effect on sustaining motivation to become nurses. Journal of Advanced Nursing; 32(3): 730-739.

[51]. Sulimana, W.A., \&Halabib, J. (2007): Critical thinking, self-esteem, and state anxiety of nursing students. Nurse Education Today; 27(2): 162-168.

[52]. Taha, N., Mansour, E., Sobhy, A., \&Youness, E. (2011): Comparison between body image and self-esteem among female nursing students in three different Arab Countries. Med. J. Cairo Univ.; 79(1): 509-517.

[53]. Takase, M., Maude, P., \& Manias, E. (2006): Impact of the perceived public image of nursing on nurses 'work behavior. Journal of Advanced Nursing, Feb; 53(3):333-43.

[54]. Tan-Kuick, G. (2012): Factors affecting student's preferences of nursing education in Singapore, DBA thesis, Southern Cross University, Lismore, NSW.

[55]. Tawash, E., Seamus, C., and Edger, A. (2012): A triangulation study: Bahraini nursing students' perceptions of nursing as a career. Journal of Nursing Education and Practice, August, Vol. 2, No. 3.

[56]. Tenhoeve, Y., Jansen, G. \& Roodbol, P. (2014): The nursing profession: public image, self-concept and professional identity. A discussion paper. Journal of Advanced Nursing 70(2), 295-309.doi: 10.1111/jan.12177.

[57]. Unsar, S., \&Issever, H. (2003) :Examination of factors affecting the self- esteem of students at Trakya University occupational school for health services. Nursing Forum Journal 2003; 6 (1):7-11.

[58]. Valizadeh, L. \& Ali, H. (2008): The process of profession's image among nursing students of bachelor`s degree: A Grounded theory study. Research Journal of Biological Sciences; 3(9):1079-98.

[59]. Varaei, S., Vaismoradi, M., Jasper, M., Faghihzadeh, S. (2012): Iranian nurses self-perception - factors influencing nursing image. J Nurs Manag;20(4):551-60. doi: 10.1111/j.1365-2834.01397.x.

[60]. Walton, R. (1974): Improving quality of working life. Harvad Business Review.

[61]. Waters, A. (2005): Nursing is the most emotionally rewarding career. Nursing Standard, 19(30), 22-26. 